\title{
GATA-4 Variants in Two Unrelated Cases with 46, XY Disorder of Sex Development and Review of the Literature
}

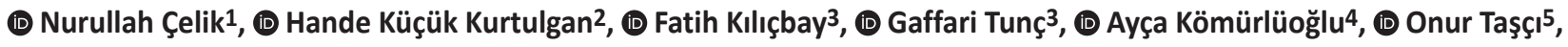 \\ (D) Cemile Ece Çağlar Şimşek4, (D) Taha Çınar4, (D) Yeşim Sıdar Duman² \\ 1 Sivas Cumhuriyet University Faculty of Medicine, Department of Pediatric Endocrinology, Sivas, Turkey \\ 2 Sivas Cumhuriyet University Faculty of Medicine, Department of Genetics, Sivas, Turkey \\ ${ }^{3}$ Sivas Cumhuriyet University Faculty of Medicine, Department of Neonatology, Sivas, Turkey \\ 4 Sivas Cumhuriyet University Faculty of Medicine, Department of Child Health and Diseases, Sivas, Turkey \\ 5 Sivas Numune Hospital, Clinic of Cardiology, Sivas, Turkey
}

\section{What is already known on this topic?}

The genetic cause of 46, XY disorders of sex development (DSD) still cannot be determined in about half of the cases. GATA-4 haploinsufficiency is one of the rare causes of DSD in genetic males (46, XY).

\section{What this study adds?}

Twenty-two cases with 46, XY DSD due to GATA-4 haploinsufficiency (nine missense variant, two copy number variation) have been reported in the literature. Phenotype varied from a mild insufficient virilization to complete female appearance. There is remarkable phenotype-genotype variation in the GATA-4-related conditions, associated with incomplete penetrance or variable expressivity.

\section{Abstract}

The genetic cause of 46, XY disorder of sex development (DSD) still cannot be determined in about half of the cases. GATA-4 haploinsufficiency is one of the rare causes of DSD in genetic males (46, XY). Twenty-two cases with 46, XY DSD due to GATA-4 haploinsufficiency (nine missense variant, two copy number variation) have been previously reported. In these cases, the phenotype may range from a mild undervirilization to complete female external genitalia. The haploinsufficiency may be caused by a sequence variant or copy number variation (8p23 deletion). The aim of this study was to present two unrelated patients with DSD due to GATA4variants and to review the phenotypic and genotypic characteristics of DSD cases related to GATA-4 deficiency.

Keywords: Disorder of sex development, GATA-4, Gonad, heart

\section{Introduction}

Disorder of sex development (DSD) is defined as atypical development of gonadal, chromosomal, or anatomical sex (1). It may be related to aneuploidy, copy number variations, or single nucleotide variants causing defects of sex hormone biosynthesis/action, and/or gonadal differentiation/development $(2,3)$. The genetic cause of 46, XY DSD still cannot be determined in about half of the cases. GATA-4 haploinsufficiency is one of the rare causes of DSD in genetic males (46, XY).
The GATA-4 gene, located on chromosome 8p23.1, encodes GATA-binding protein $4(G A T A-4)$, a transcription factor that is essential for cardiac and gonadal development $(4,5,6)$. By interacting with NR5A1, FOG-2, and WT1, the GATA4 protein regulates the expression of sex-determining genes, SRY, SOX-9, and anti-Müllerian hormone (AMH) (7). It has also been shown that the protein modulates a couple of steroidogenic genes that are essential for sexual differentiation $(7,8)$.
Address for Correspondence: Nurullah Celik MD, Sivas Cumhuriyet University Faculty of Medicine, Department of Pediatric Endocrinology, Sivas, Turkey

Phone:+90 5056736145 E-mail: celiknurullah@hotmail.com, ncelik@cumhuriyet.edu.tr ORCID: orcid.org/0000-0003-1583-6807
Conflict of interest: None declared Received: 05.05.2021 Accepted: 28.07.2021 
GATA-4 haploinsufficiency as a cause of congenital heart disease (CHD) is a well-known association and nearly 200 variants have been reported to date. However, to the best of our knowledge, there are only twenty-two cases of GATA-4 related DSD in the literature $(7,9,10,11,12,13,14)$. In these cases, the phenotype may range from a mild undervirilization to complete female external genitalia. The haploinsufficiency may be caused by a sequence variant or copy number variation (8p23 deletion). Based on a large international cohort study, only 1-2\% of 46, XY DSD cases may be related to GATA-4 gene $(12,15)$.

The aim of this study was to present two unrelated patients with DSD due to GATA-4 variants and to review the phenotypic and genotypic characteristics of DSD cases related to GATA-4 deficiency.

\section{Case Reports}

DNA was extracted from peripheral blood sample by using QIAamp DNA Blood Mini Kit (QIAGEN, Hilden, Germany) according to manufacturers instructions. A targeted gene panel for 46, XY DSD was used and samples were analyzed by a next-generation sequencing technique using a custom panel kit (Twist Bioscience, San Francisco, CA, USA). The gene panel included $A M H, A M H R 2, A K R 1 C 2, A R$, ARX, ATRX, B3GALTL, CYB5A, CYP11A1, CYP17A1, DHCR7, DHH, GATA4, HCCS, HSD17B3, LHCGR, MAMLD1, MAP3K1, NR5A1, OPHN1, SOX9, SRD5A2, SRY, WT1, ZFPM2. The Genemaster (www.egenemaster.com) program was used for the analysis of the obtained data. Detected changes were analyzed using genomAD (https://gnomad. broadinstitute.org), dbSNP (16), VarSome (17), and Clinvar (18) databases and interpreted according to The American College of Medical Genetics and Genomics (ACGM) criteria (19). Written consent was obtained from parents of the probands.
Follicle stimulating hormone, luteinizing hormone, estradiol, total testosterone, AMH, adrenocorticotrophic hormone, cortisol and dehydroepiandrosterone sulfate (DHEA-SO4) levels were measured by an automated electrochemiluminescence immunoassay (Roche Cobas 8000, Roche Diagnostics GmbH, Mannheim, Germany) using the standard reagent kits supplied by the instrument manufacturer. Dihydrotestosterone and 17-OH progesterone levels were measured using liquid chromatography-tandem mass spectrometry (LC-MS/MS).

\section{Case 1}

A neonate was hospitalized to the neonatal intensive care unit due to prematurity, and respiratory distress. The baby was delivered from a 20-year-old mother at 32 weeks 3 days, with a birth weight of 1960 g. The parents were consanguineous and the baby was a first child. Delivery was by cesarean section, due to loss of Doppler activity and polyhydramnios. Physical examination revealed dysmorphic ears, epicanthus, hypertelorism, umbilical hernia, standing trigger finger, bilateral simian line, central hypotonicity, micropenis $(1.5 \times 1 \mathrm{~cm})$, scrotal hypoplasia, and bilateral undescended testis. Atrial septal defect (ASD), patent ductus arteriosus, and pulmonary stenosis were diagnosed with echocardiographic assessment at the fourth month of age. Adrenal gland hormones were within normal limits according to age and gender. Pituitary-gonadal functions were in the normal range, consistent with mini puberty. Gonad and adrenal function tests are presented in Table 1.

The chromosomal analysis revealed a 46, XY karyotype. Targeted gene panel sequencing for 46, XY DSD identified a heterozygous, novel variant in Exon 2 of the GATA-4 gene, c.337A > C (p.Thr113Pro). This variant had not been previously reported. VarSome classified this substitution as "Variant of Uncertain Significance". In silico analysis revealed

Table $1.15^{\text {th }}$ day basal gonadal and adrenal functions of the cases

\begin{tabular}{|c|c|c|c|}
\hline & Case 1 & Case 2 & References \\
\hline FSH, IU/L & 4 & 0.5 & $0.16-4.1$ \\
\hline $\mathrm{LH}, \mathrm{IU} / \mathrm{L}$ & 4 & 3.79 & $0.02-7$ \\
\hline Total testosterone, $\mathrm{nmol} / \mathrm{L}$ & 15.09 & 5.24 & $2.6-13.86$ \\
\hline Dihydtestosterone, $\mathrm{nmol} / \mathrm{L}$ & 1.64 & 1.88 & $0.4-2.92$ \\
\hline Cortisol, nmol/L & 105.94 & 121.39 & $55-303$ \\
\hline DHEA-SO $_{4}, \mu \mathrm{mol} / \mathrm{L}$ & 8.35 & 14.32 & $0.84-11.68$ \\
\hline 17-OH-pProgesterone, $\mathrm{nmol} / \mathrm{L}$ & 14.57 & 2.88 & $0.1-6.06$ \\
\hline
\end{tabular}

ACTH: adrenocorticotrophin, AMH: anti-Müllerian hormone, DHEA-SO4: dehydroepiandrosterone sulfate, FSH: follicle stimulating hormone, LH: luteinizing hormone 
eight pathogenic predictions (BayesDel_addAF, DEOGEN2, FATHMM-MKL, M-CAP, MutationTaster, PrimateAI and SIFT) and four benign predictions (DANN, EIGEN, MVP and MutationAssessor). Segregation analysis showed that the variant was de novo (Figure 1). We believe this new variant is compatible in terms of genotype and phenotype correlation.

\section{Case 2}

A three day-old patient was referred to the endocrinology clinic due to ambiguous genitalia. He was born to nonconsanguineous parents at 38 gestational weeks, with a birth weight of $3185 \mathrm{~g}$. Microphallus, bifid scrotum, perineoscrotal hypospadias were evident on physical examination.
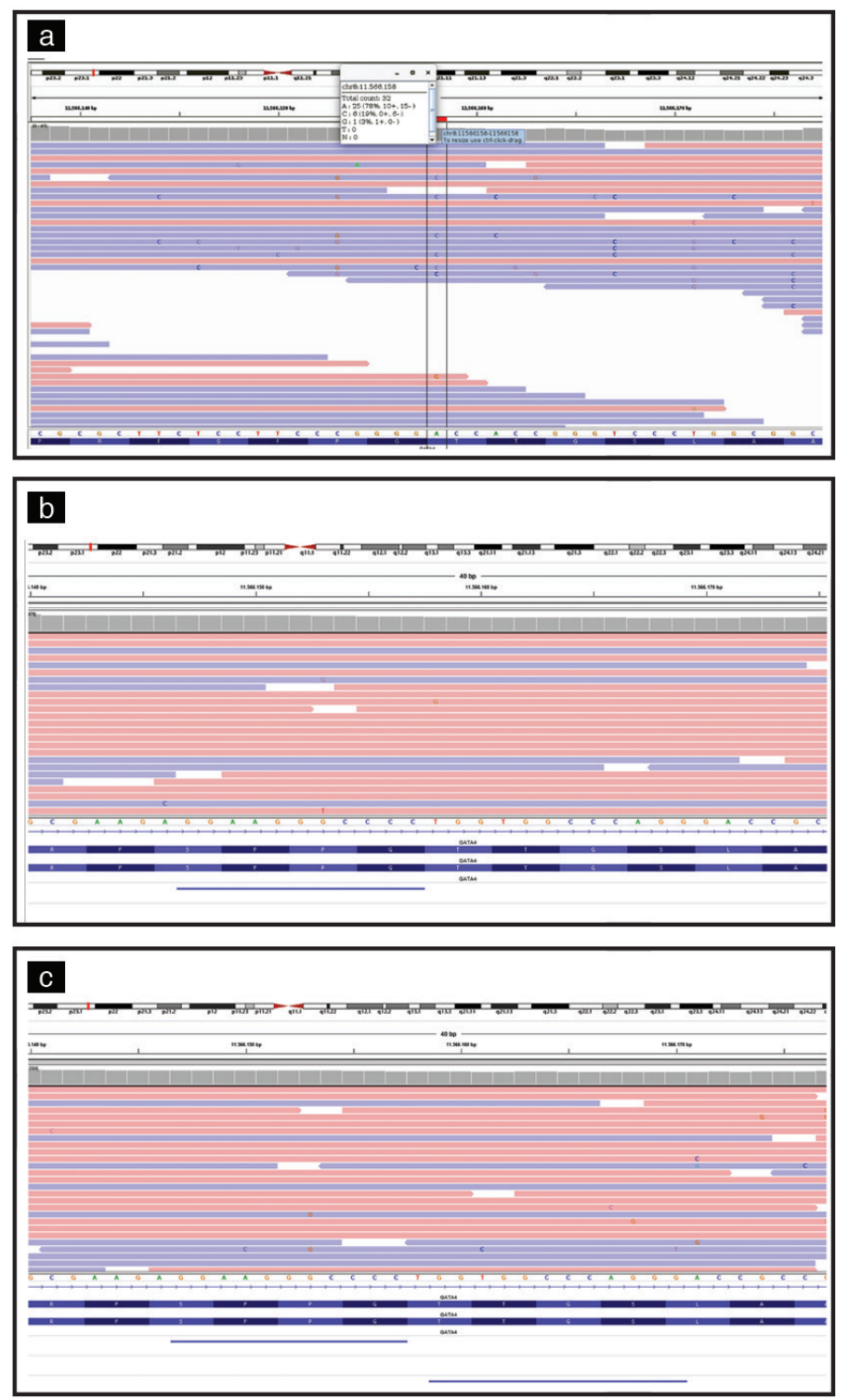

Bilateral gonads were palpable in the scrotum. System examination was normal, except for ptosis in the left eye. CHD was not detected by echocardiography. Adrenal gland hormones were within normal limits according to age and gender. Pituitary-gonadal functions were in the normal range, consistent with mini puberty. Gonad and adrenal function tests are presented in Table 1. Chromosome analysis revealed a 46, XY karyotype. Targeted gene panel sequencing for 46, XY DSD identified a heterozygous, likely pathogenic variant in Exon 2 of the GATA-4 gene, c. 487C > T (p. Pro163Ser). In the segregation analysis, the mother did not carry this variant, The analysis could not be done for the father (Figure 1).
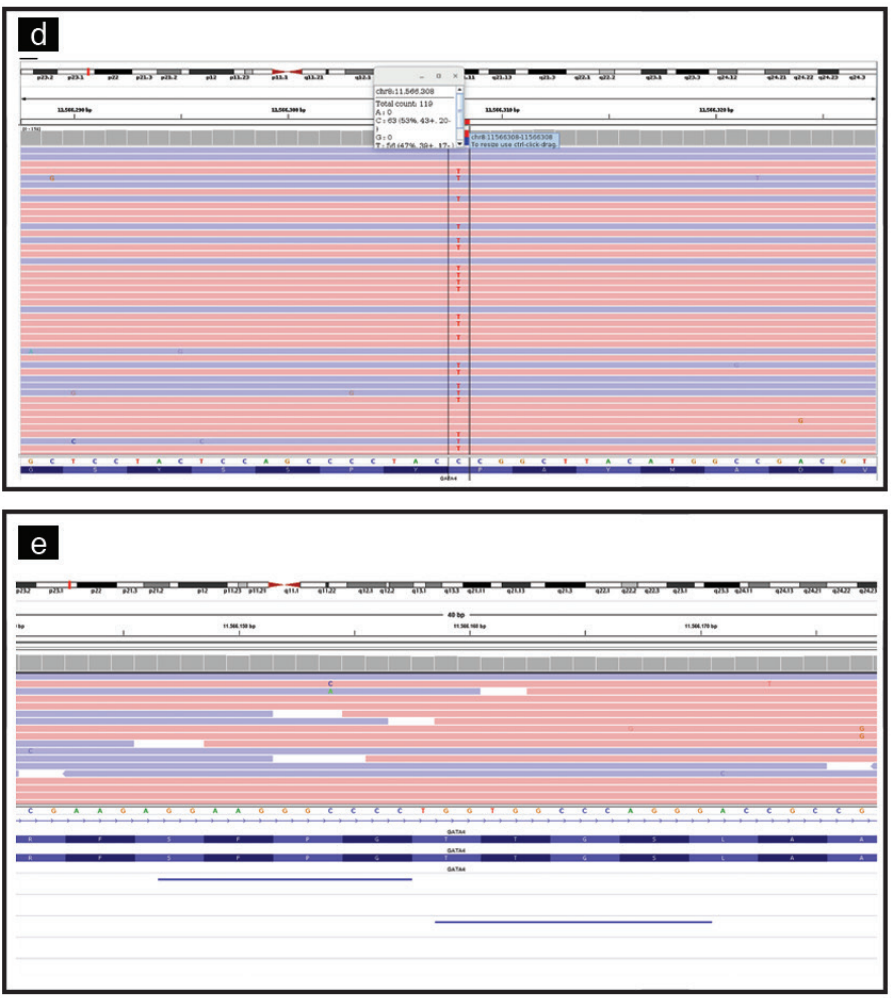

Figure 1. Integrative Genomics Viewer (IGV) images of NGS results of GATA-4 gene located at chromosome 8 . a) Shows the heterozygous c.337 A > C variant (p.Thr113Pro) in the GATA-4 gene in Case 1. b, c) The relevant gene variant was not detected in parents of Case 1. d) Shows the c.487 C > T variant (p.Pro487Ser) in the GATA-4 gene in Case 2. e) The relevant gene variant was not detected in mother of the Case 2 (the analysis could not be done for the father) 


\section{Discussion}

Twenty-two cases with 46, XY DSD due to GATA-4 haploinsufficiency (nine missense variant, two copy number variation) have been previously reported (Table 2). Eighteen of these cases ( $82 \%$ ) were raised as a male. Only two (9\%) cases were accompanied by CHD, specifically ASD and ventricular septal defect. Phenotype varied from mild insufficient virilization to a complete female appearance.

The first report by Lourenço et al. (9) reported three DSD cases having the same missense variant in the GATA-4 gene. This variant was located in the zinc finger domain, which is responsible for DNA binding and protein interaction of the GATA-4 protein. Moreover, they showed a $50 \%$ reduction in AMH activity with expression analysis of this variant. While the index case had only DSD, the brother and one cousin with the same variant as the index case both had DSD and CHD. Furthermore, the mother and aunt of the index case, who carried the same variant, had neither DSD nor CHD.

In another study evaluating 278 cases with 46 XY DSD, four different GATA-4 variants were detected in seven cases (12). However, the authors reported that only one of the four variants was pathogenic, and the others were benign, in their later work (15). In particular, they suggested that variants in the GATA-4 gene located outside the N-terminal region of the zinc finger domain should be approached with suspicion that there will be a causal relationship with DSD. Although van den Bergen et al. (15) mentioned that the p.P407Q variant in the GATA-4 gene, the most commonly reported GATA-4 variant in $46 \mathrm{XY}$ DSD, was benign, it has been shown in experimental studies that the variant causes reduced expression of both $A M H$ and $S R Y$ genes $(13,14)$.

\begin{tabular}{|c|c|c|c|c|c|c|}
\hline Case & $\begin{array}{l}\text { Sex of } \\
\text { rearing }\end{array}$ & Additional findings & CHD & Phenotype & Genotype & References \\
\hline 1 & M & & & $\begin{array}{l}\text { Fused hypoplastic labioscrotal fold, perineal hypospadias, } \\
\text { hypoplasia of corpus cavernosum, bilateral cryptorchidism } \\
\text { (inguinal) }\end{array}$ & $\begin{array}{l}\text { p.G221R } \\
(\mathrm{n}=3)\end{array}$ & 9 \\
\hline 2 & M & & ASD & Microphallus, bilateral cryptorchidism (inguinal) & & \\
\hline 3 & M & & & $\begin{array}{l}\text { Fused labioscrotal folds, hypospadias, bilateral cryptorchidism } \\
\text { (inguinal) }\end{array}$ & & \\
\hline 4 & M & $\begin{array}{l}\text { Congenital adrenal } \\
\text { hypoplasia }\end{array}$ & & Complete gonadal dysgenesis, female external genitalia & $8 \mathrm{p} 23$ deletion & 10 \\
\hline 5 & M & & & $\begin{array}{l}\text { Perineal hypospadias, bifid scrotum, bilateral cryptorchidism, } \\
\text { Mullerian structures absent }\end{array}$ & 8p23 deletion & 11 \\
\hline 6 & M & & & Micropenis, cryptorchidism & p.W228C & 12 \\
\hline 7 & M & & & $\begin{array}{l}\text { Perineal hypospadias, chordee, and penoscrotal transposition, } \\
\text { cryptorchidism }\end{array}$ & p.A346V & \\
\hline 8 & M & & & Perineal hypospadias, (gonad position unknown) & p.P394T & \\
\hline 9 & $\mathrm{~F}$ & & & Female (no virilization), inguinal bilateral testes, no uterus & & \\
\hline 10 & M & Imperforate anus & & Penile hypospadias, cryptorchidism & p.P407Q & \\
\hline 11 & M & & & Scrotal hypospadias, testes palpable, hypoplastic uterus & & \\
\hline 12 & M & & & Perineal hypospadias cryptorchidism & & \\
\hline 13 & M & & & Male type genitalia, cryptorchidism with or without micropenis & p.R265C n = 1 & 13 \\
\hline $\begin{array}{l}14- \\
17\end{array}$ & M & & & & $\begin{array}{l}\text { p.P407Q } \\
\mathrm{n}=4\end{array}$ & \\
\hline 18 & $\mathrm{~F}$ & Autism & VSD & $\begin{array}{l}\text { Clitoral hypertrophy, fused labia with posterior raphe, gonads } \\
\text { palpable in inguinal canal, rudimentary uterus }\end{array}$ & p.C238R & 7 \\
\hline 19 & M & & & Micropenis, hypospadias, bilateral cryptorchidism & p.W228C & \\
\hline 20 & M & Severe obesity & & Micropenis, bilateral cryptorchidism (inguinal) & p.P226L & \\
\hline 21 & M & & & Micropenis, perineal hypospadias, bilateral cryptorchidism & p.R215G & 14 \\
\hline 22 & $\mathrm{~F}$ & & & Complete female genitalia & p.P407Q & \\
\hline 23 & M & $\begin{array}{l}\text { Dysmorphic } \\
\text { ear, epicanthus } \\
\text { hypertelorism } \\
\text { umbilical hernia }\end{array}$ & $\begin{array}{l}\text { ASD, } \\
\text { VSD, PS }\end{array}$ & $\begin{array}{l}\text { Microphallus, scrotal hypoplasia, bilateral cryptorchidism } \\
\text { (inguinal) }\end{array}$ & p.T113P & \\
\hline 24 & M & Ptosis & & Perineoscrotal hypospadias, microphilus, bifid scrotum & p.p163S & \\
\hline
\end{tabular}

ASD: atrial septal defect, CHD: congenital heart disease, F: female, M: male, PS: pulmonary stenosis, VSD: ventricular septal defect 
Furthermore, this variant was found to be associated with CHD in previous studies (15).

Our unrelated patients had two different variants in the GATA-4 gene. Undoubtedly, expression analysis is needed to establish a causal relationship between these variants and DSD, which is the most important limitation of the study. However, although these two variants were not located in the zinc finger domain, they were close to the $\mathrm{N}$-terminal part of the domain. On the other hand, the first case (Case 1) with a novel variant of uncertain significance also had CHD, which may be explained by GATA-4 deficiency. We also performed the microarray analysis due to other accompanying syndromic findings in the first case, and this was evaluated as normal. Further genetic studies are needed in this case. The GATA-4 variant in the second case (Case 2), which was reported in cases with previous patients with $\operatorname{CHD}(20,21,22)$, was classified as likely pathogenic according to ACMG criteria. To the best of our knowledge, the latter variant has not been previously associated with DSD. This may be a striking example of the phenotype-genotype mismatch associated with the GATA-4 gene.

The phenotype-genotype variation in GATA-4 related conditions may be associated with incomplete penetrance or variable expressivity. However, it is unclear why GATA-4 variant related CHD is encountered more often than DSD. The answer of this question will perhaps enable us to better understand the phenotype-genotype relations.

\section{Conclusion}

Variants of the gene encoding the GATA-4 protein may be responsible for the etiology in $46, \mathrm{XY}$ DSD. The phenotype may range from a mild undervirilization to complete female external genitalia. The CHD or DSD can be isolated or combined; GATA-4 gene defects should be considered in cases with both CHD and DSD.

\section{Ethics}

Informed Consent: Consent form was filled out by all participants.

Peer-review: Externally peer-reviewed.

\section{Authorship Contributions}

Concept: Nurullah Çelik, Hande Küçük Kurtulgan, Fatih Kılıçbay, Gaffari Tunç, Ayça Kömürlüoğlu, Data Collection or Processing: Nurullah Çelik, Hande Küçük Kurtulgan, Onur Taşçı, Cemile Ece Çağlar Şimşek, Taha Çınar, Analysis or Interpretation: Nurullah Çelik, Hande Küçük Kurtulgan, Fatih Kılıçbay, Gaffari Tunç, Literature Search: Nurullah
Çelik, Hande Küçük Kurtulgan, Yeşim Sıdar Duman, Writing: Nurullah Çelik.

Financial Disclosure: The authors declared that this study received no financial support.

\section{References}

1. Hughes IA, Houk C, Ahmed SF, Lee PA; Lawson Wilkins Pediatric Endocrine Society/European Society for Paediatric Endocrinology Consensus Group. Consensus statement on management of intersex disorders. J Pediatr Urol 2006;2:148-162. Epub 2006 May 23

2. Croft B, Ohnesorg T, Sinclair AH. The Role of Copy Number Variants in Disorders of Sex Development. Sex Dev 2018;12:19-29. Epub 2017 Nov 17

3. Barseghyan H, Délot EC, Vilain E. New technologies to uncover the molecular basis of disorders of sex development. Mol Cell Endocrinol 2018;468:60-69. Epub 2018 Apr 13

4. Viger RS, Mertineit C, Trasler JM, Nemer M. Transcription factor GATA4 is expressed in a sexually dimorphic pattern during mouse gonadal development and is a potent activator of the Müllerian inhibiting substance promoter. Development 1998;125:2665-2675.

5. Molkentin JD, Lin Q, Duncan SA, Olson EN. Requirement of the transcription factor GATA4 for heart tube formation and ventral morphogenesis. Genes Dev 1997;11:1061-1072.

6. Kuo CT, Morrisey EE, Anandappa R, Sigrist K, Lu MM, Parmacek MS, Soudais C, Leiden JM. GATA4 transcription factor is required for ventral morphogenesis and heart tube formation. Genes Dev 1997;11:10481060

7. Martinez de LaPiscina I, de Mingo C, Riedl S, Rodriguez A, Pandey AV, Fernández-Cancio M, Camats N, Sinclair A, Castaño L, Audi L, Flück CE. GATA4 Variants in Individuals With a 46,XY Disorder of Sex Development (DSD) May or May Not Be Associated With Cardiac Defects Depending on Second Hits in Other DSD Genes. Front Endocrinol (Lausanne) 2018;9:142.

8. Viger RS, Guittot SM, Anttonen M, Wilson DB, Heikinheimo M. Role of the GATA family of transcription factors in endocrine development, function, and disease. Mol Endocrinol 2008;22:781-798. Epub 2008 Jan 3

9. Lourenço D, Brauner R, Rybczynska M, Nihoul-Fékété C, McElreavey K, Bashamboo A. Loss-of-function mutation in GATA4 causes anomalies of human testicular development. Proc Natl Acad Sci U S A 2011;108:15971602. Epub 2011 Jan 10

10. White S, Ohnesorg T, Notini A, Roeszler K, Hewitt J, Daggag H, Smith C, Turbitt E, Gustin S, van den Bergen J, Miles D, Western P, Arboleda V, Schumacher V, Gordon L, Bell K, Bengtsson H, Speed T, Hutson J, Warne G, Harley V, Koopman P, Vilain E, Sinclair A. Copy number variation in patients with disorders of sex development due to $46, \mathrm{XY}$ gonadal dysgenesis. PLoS One 2011;6:e17793.

11. Wagner-Mahler K, Kurzenne JY, Gastaud F, Hoflack M, Panaia Ferrari P, Berard E, Giuliano F, Karmous-Benailly H, Moceri P, Jouannelle C, Bourcier M, Robart E, Morel Y. Is interstitial 8p23 microdeletion responsible of 46,XY gonadal dysgenesis? One case report from birth to puberty. Mol Genet Genomic Med 2019;7:e558. Epub 2019 Jan 28

12. Eggers S, Sadedin S, van den Bergen JA, Robevska G, Ohnesorg T, Hewitt J, Lambeth L, Bouty A, Knarston IM, Tan TY, Cameron F, Werther G, Hutson J, O'Connell M, Grover SR, Heloury Y, Zacharin M, Bergman P, Kimber C, Brown J, Webb N, Hunter MF, Srinivasan S, Titmuss A, Verge CF, Mowat D, Smith G, Smith J, Ewans L, Shalhoub C, Crock P, Cowell C, Leong GM, Ono M, Lafferty AR, Huynh T, Visser U, Choong CS, McKenzie F, Pachter N, Thompson EM, Couper J, Baxendale A, 
Gecz J, Wheeler BJ, Jefferies C, MacKenzie K, Hofman P, Carter P, King RI, Krausz C, van Ravenswaaij-Arts CM, Looijenga L, Drop S, Riedl S, Cools M, Dawson A, Juniarto AZ, Khadilkar V, Khadilkar A, Bhatia V, Dũng VC, Atta I, Raza J, Thi Diem Chi N, Hao TK, Harley V, Koopman P, Warne G, Faradz S, Oshlack A, Ayers KL, Sinclair AH. Disorders of sex development: insights from targeted gene sequencing of a large international patient cohort. Genome Biol 2016;17:243.

13. Igarashi M, Mizuno K, Kon M, Narumi S, Kojima Y, Hayashi Y, Ogata T, Fukami M. GATA4 mutations are uncommon in patients with $46, X Y$ disorders of sex development without heart anomaly. Asian J Androl 2018;20:629-631.

14. Choi JH, Lee Y, Oh A, Kim GH, Yoo HW. Molecular Characteristics of Sequence Variants in GATA4 in Patients with 46,XY Disorders of Sex Development without Cardiac Defects. Sex Dev 2019;13:240-245. Epub 2020 Sep 26

15. van den Bergen JA, Robevska G, Eggers S, Riedl S, Grover SR, Bergman PB, Kimber C, Jiwane A, Khan S, Krausz C, Raza J, Atta I, Davis SR, Ono M, Harley V, Faradz SMH, Sinclair AH, Ayers KL. Analysis of variants in GATA4 and FOG2/ZFPM2 demonstrates benign contribution to 46,XY disorders of sex development. Mol Genet Genomic Med 2020;8:e1095. Epub 2020 Jan 21

16. Sherry ST, Ward MH, Kholodov M, Baker J, Phan L, Smigielski EM, Sirotkin K. dbSNP: the NCBI database of genetic variation. Nucleic Acids Res 2001;29:308-311.

17. Kopanos C, Tsiolkas V, Kouris A, Chapple CE, Albarca Aguilera M, Meyer R, Massouras A. VarSome: the human genomic variant search engine. Bioinformatics 2019;35:1978-1980.
18. Landrum MJ, Lee JM, Benson M, Brown G, Chao C, Chitipiralla S, Gu B, Hart J, Hoffman D, Hoover J, Jang W, Katz K, Ovetsky M, Riley G, Sethi A, Tully R, Villamarin-Salomon R, Rubinstein W, Maglott DR. ClinVar: public archive of interpretations of clinically relevant variants. Nucleic Acids Res 2016;44:862-868. Epub 2015 Nov 17

19. Richards S, Aziz N, Bale S, Bick D, Das S, Gastier-Foster J, Grody WW, Hegde M, Lyon E, Spector E, Voelkerding K, Rehm HL; ACMG Laboratory Quality Assurance Committee. Standards and guidelines for the interpretation of sequence variants: a joint consensus recommendation of the American College of Medical Genetics and Genomics and the Association for Molecular Pathology. Genet Med 2015;17:405-424. Epub 2015 Mar 5

20. Li RG, Xu YJ, Wang J, Liu XY, Yuan F, Huang RT, Xue S, Li L, Liu H, Li YJ, Qu XK, Shi HY, Zhang M, Qiu XB, Yang YQ. GATA4 Loss-of-Function Mutation and the Congenitally Bicuspid Aortic Valve. Am J Cardiol 2018;121:469-474. Epub 2017 Nov 23

21. Zhang W, Li X, Shen A, Jiao W, Guan X, Li Z. GATA4 mutations in 486 Chinese patients with congenital heart disease. Eur J Med Genet 2008;51:527-535. Epub 2008 Jul 11

22. Liu Y, Li B, Xu Y, Sun K. Mutation Screening of Gata4 Gene in CTD Patients Within Chinese Han Population. Pediatr Cardiol 2017;38:506512. Epub 2017 Feb 4 